\title{
Assessment and analysis of the state manage- ment of labor resources as a factor in the de- velopment of the mining industry in the region
}

\author{
Natalia Zaruba*, Eduard Wolfson, Konstantin Vostrikov, Olga Nikiforova, and Elena \\ Sedelnikova
}

EDP Sciences, Kuzbass State Technical University named after T. F. Gorbachev, Kemerovo, Russia

\begin{abstract}
The subject of the research in this article is to identify the role and importance of public management of labor resources in the region as a factor in the development of the mining industry by improving the level of professionalism of specialists who evaluate and analyze the labor resources of the mining industry. The purpose of the study is to prepare proposals aimed at implementing effective management of the mining industry's labor resources based on the use of modern methods of assessment and analysis. Research methods. The study used comparative and institutional approaches, as well as empirical methods - methods of observation and comparison. Research materials. In the preparation of the scientific article, statistical data were used to characterize the movement of labor and the use of working time, as well as working conditions and the level of injuries in the mining region of the Kemerovo region - Kuzbass. The analysis and evaluation of the published data were carried out in the study in order to identify management reserves based on the evaluation and analysis of the data obtained. The results obtained can contribute to improving the performance of mining enterprises in attracting qualified personnel and effective management of labor resources. The study shows that only a scientific approach to the application of the functions of management, evaluation and analysis of public management of human resources could be considered as a factor in the development of the mining industry, which requires research attention, since problems can be solved only on the basis of their identification. As such, we have identified an underestimation of the role and importance of a comprehensive analysis and assessment of the problems of public management of human resources in the mining industry. The study showed that the system of human resources management in the mining industry in order to assess and analyze them on the basis of an integrated approach requires the organization and implementation of research related to the identification of correlations of key elements of the management system. The problem of reducing number of trained specialists and the professionalism of personnel remains a well-known problem in the mining industry in the Kemerovo region.

The results of our research were discussed at annual scientific conferences devoted to topical issues of public administration development, including
\end{abstract}

\footnotetext{
${ }^{*}$ Corresponding author: zna.gmu@ $@$ kuzstu.ru
} 
in the mining industry, with the involvement of officials of relevant structures of regional government bodies. In conclusion, it could be noted that the obtained intermediate scientific results of human resource management in the mining sector will significantly contribute to the timely introduction of modern and effective technologies into the practice of public administration.

\section{Introduction}

The modern view of science on the socio-economic problems of state management of labor resources in the mining industry is due to a number of external and internal factors inherent both in the industry itself and in society as a whole: russian and international. Despite this, many researchers agree that the domestic mining industry maintains a trend towards sustainable functioning or development, despite the pandemic and the global crisis, and also has prospects. This is confirmed by data, for example, on the growth in the number of high-performance jobs at mining enterprises in the study region in 2018 compared to the previous year ( $2017-104551,2018$ 107443 , which is $2.8 \%$ higher) [ 5, p. 99]. At the same time, in science, there is also the position of other authors that the stability of the energy market, both global and domestic, is far from favorable. The market of the mining industry, in particular, coal, is experiencing some difficulties due to the fall in demand for coal, which is fundamental for the Kemerovo region - Kuzbass region. At the same time, we should not underestimate a number of acute problems that hinder the development of the mining industry, including the problem of managing the region's labor resources. Relevance of the topic. It is known that no problem can be solved only by economic or political means. This is also relevant to the problem of the development of the mining industry in the region. Improving the assessment and analysis of state management of labor resources for the development of the mining industry in the region as an effective lever in solving the problem of shortage of labor resources in modern conditions relevant do not only for society and the state, in connection with the fact of unemployment, in general, but also specifically for a particular industry. This is due to the modern active processes of digitalization, automation, robotization, modernization of public administration, etc. Therefore, the modern role of management as a science is to integrate its capabilities and achievements with other sciences in order to develop both the entire society and, for example, the mining industry to achieve the necessary or desired result. At the same time, it is important to take into account that in the Kemerovo region-Kuzbass mining industry, in which at the end of $2019.76 .5 \%$ of employees work in private-owned organizations, and $23.1 \%$ work in joint-owned organizations $[5, \mathrm{p} .93]$. This requires such approaches to decisionmaking on its development that they correspond to the real state of affairs in this matter, namely approaches based on the principles of cooperation, mutual understanding and integration.

The development of the topic in the literature. In modern science, certain aspects of improving the assessment and analysis of public administration of labor resources reflected. The ideas of solving the problem under study reflected in the works of Horeshok A. A., Zhironkin S. A., Zhironkina O. V., Tyulenev M. A. (2016). [6]. The issue of corporate responsibility in the mining industry with a view to its sus- 
tainable development are studied in the work of Yarmusevits, V.; Ilisko, D.; Badzhanova, J.; Yukssa, V.; Petrova, M. [ 3-4, et al.].

The purpose of the introduction is to demonstrate the interest of foreign and domestic specialists in the problem of finding effective strategies for the interaction of regional government bodies with organizations and institutions of the mining industry, as well as to analyze materials and documents on this problem as a basis for integration and cooperation. Since the mining industry in the Kemerovo region-Kuzbass region is a private sector, it is not necessary to talk about the vertical management, but the labor resources of this industry are the residents of the region, which is the subject of concern of the state authorities at any level.

Labor resources, as a part of the population that is able to work (in accordance with labor legislation) in the mining industry in the Kemerovo region - Kuzbass, despite the historical understanding that this is the land of miners and miners, are undergoing market deformations with the resulting consequences: cuts, layoffs, a shortage of highly qualified personnel, etc.

Taking into account that we consider as ways of development of the mining industry in the Kemerovo region - Kuzbass region we consider an integrative approach in management, then as one of the ways we propose to consider the analysis and evaluation of labor resources in the basis of scientific research obtained by statistical methods.

The main tasks of mining labor market statistics in the Kemerovo Region-Kuzbass region are:

* collecting information on the number of employed and unemployed as two components of the labor force;

* to study of the state and trends in the Russian labor market using indicators of the level of employment and unemployment;

* study of the composition of the employed and unemployed according to different characteristics (gender, age, industries and sectors of the economy, by regions of the country and other characteristics) in order to regulate the labor market, develop programs to increase the level of employment, employ the unemployed, their professional retraining, etc.

Annually published data from statistical federal or regional bodies for management professionals is a tool for analysis, evaluation, identification of problems and management decision-making. The main phenomena for this should include: the movement of workers in the mining industry; the number of laid-off employees; the need for employees for vacant positions; the number of employees employed in dangerous or difficult working conditions; the number of employees employed in jobs associated with a stressful labor process, etc.

The first phenomenon: the study of the nature of the movement of mining workers in the Kemerovo region-Kuzbass region showed that, despite the increase in the total number of employees employed in 2018, compared to 2017 by $12 \%$ (Ill 1).

Table 1. Movement of employees by type of economic activity

\begin{tabular}{|l|l|l|l|l|l|}
\hline & $\begin{array}{l}\text { Employees } \\
\text { accepted }\end{array}$ & $\begin{array}{l}\text { Including the } \\
\text { additional } \\
\text { places en- } \\
\text { tered }\end{array}$ & $\begin{array}{l}\text { Employees } \\
\text { dropped out }\end{array}$ & $\begin{array}{l}\text { In connection } \\
\text { with the re- } \\
\text { duction of }\end{array}$ & $\begin{array}{l}\text { At your } \\
\text { own re- } \\
\text { quest }\end{array}$ \\
\hline Mining operations & 3159 & 23619 & 118 & 16159 \\
\hline $\mathbf{2 0 1 7}$ & 26048 & 2581 & 25864 & 189 & 18447 \\
\hline $\mathbf{2 0 1 8}$ & 30278 &
\end{tabular}




\begin{tabular}{|l|l|l|l|l|l|}
\hline \multicolumn{5}{|l|}{ Coal mining } \\
\hline $\mathbf{2 0 1 7}$ & 24962 & 3158 & 22346 & 87 & 15510 \\
\hline $\mathbf{2 0 1 8}$ & 26262 & 2656 & 24937 & 176 & 17915 \\
\hline \multicolumn{2}{|l|}{ Extraction of other minerals } & - & 611 & 3 & 314 \\
\hline $\mathbf{2 0 1 7}$ & 467 & 8 & 368 & - & 336 \\
\hline $\mathbf{2 0 1 8}$ & 387 & - & \\
\hline
\end{tabular}

In general, the trend of deterioration of the state of labor resources continues. This is confirmed by the fact that in 2018 , the employment of additional jobs introduced in the industry decreased by $20 \%, 10 \%$ more employees left the industry, $16 \%$ more left due to the reduction, $11 \%$ more left on their own. Data on the types of industry (coal mining or mining of other minerals) also indicates a deterioration in labor trends. In the field of coal mining in 2018, the number of employees hired for additional jobs decreased by $10 \%, 11 \%$ more employees left the industry, $20 \%$ more retired due to the reduction, and $12 \%$ more retired on their own. The situation is similar in the field of extraction of other minerals. [5, p. 99].

Thus, the analysis of the movement of workers by types of mining industry activities in the Kemerovo region-Kuzbass region allows us to assess the nature of the movement as negative, as evidenced by the data provided, which is the basis for making a management decision to eliminate this problem.

The second phenomenon: the analysis of the distribution of the number of laid-off employees in the mining industry in the Kemerovo region - Kuzbass region in 2018 allows, on the one hand, to state that there is not the most critical situation in comparison with other types of activities, since $5.6 \%$ is not the lowest indicator (Ill. 1)

\section{Distribution of the number of dismissed by reduction in staff by type of economic activity in $\mathbf{2 0 1 8}$}

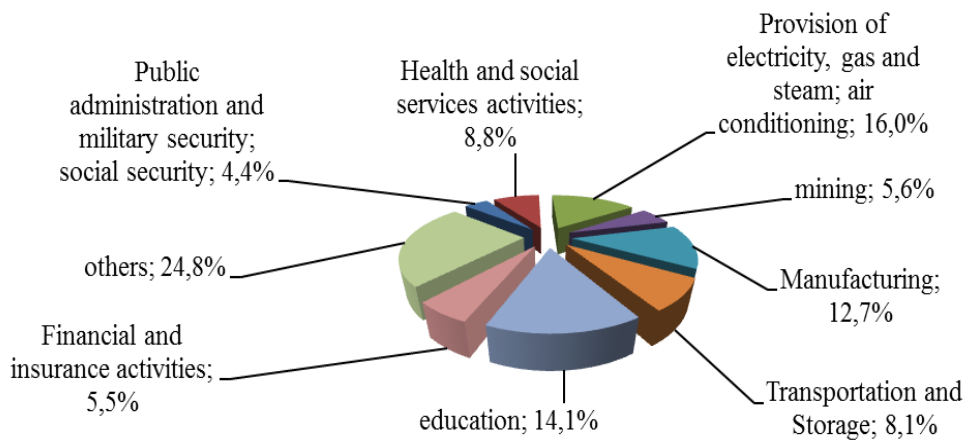

Fig. 1. Distribution of the number of laid-off employees by type of economic activity in 2018 .

However, when evaluating, it should be noted that based on the total number of working specialists in this industry, and on the amount of their remuneration, in comparison with other industries presented in this figure, this indicator should be considered negative, requiring the development and adoption of an effective management decision $(5$, p.123124).

The third phenomenon: estimation of the number of required employees for vacant jobs by type of economic activity in the mining industry in the Kemerovo region - Kuzbass 
region on the basis of data from the regional statistical office (Table 2) [5, p. 130 ] reveals the presence of a problem that requires an effective decision of the owners.

Table 2. The number of required employees for vacant jobs by type of economic activity (at the end of the year; people).)

\begin{tabular}{|l|l|l|l|}
\hline & & $\mathbf{2 0 1 7}$ & $\mathbf{2 0 1 8}$ \\
\hline 1 & Mining operations: & 1795 & 2089 \\
\hline 1.1 & Coal mining & 1780 & 2064 \\
\hline 1.2 & Mining of other minerals & 13 & 25 \\
\hline
\end{tabular}

As you can see, based on the analysis of data in 2018. (Table.2), the number of required employees for vacant jobs in the mining industry in the Kemerovo region - Kuzbass region increased by $12 \%$; specifically, in the coal industry by $11.3 \%$, and in the field of mining of other minerals by almost 2 times [5, p. 130 ]. This also suggests that there is a problem of labor resources in the mining industry in the Kemerovo Region - Kuzbass region.

The fourth phenomenon: analysis and evaluation of underemployment by type of economic activity in the mining industry in the Kemerovo region - Kuzbass region based on data from the regional statistical office (Table.3) it is important, as it is an indicator of the effectiveness of the use and search for a reserve for the development of labor resources. The data offered for analysis and evaluation by the regional statistical office to employers of all forms of ownership regarding underemployment indicate that there are or are not problems with this indicator. [ 5, p. 133].

The very fact of underemployment of labor resources in its content should be in the field of view of the management as a problem, since permanent or temporary work in society perceived as guaranteed employment and not guaranteed.

Table 3. Underemployment by type of economic activity (annual average; people)

\begin{tabular}{|l|l|l|l|l|}
\hline & \multicolumn{2}{|l|}{$\begin{array}{l}\text { Number of part-time employees on the } \\
\text { roster }\end{array}$} & $\begin{array}{l}\text { The number of } \\
\text { employees in the } \\
\text { list who are simp- } \\
\text { ly due to the fault } \\
\text { of the employer } \\
\text { and for reasons } \\
\text { independent of the } \\
\text { employer and } \\
\text { employee }\end{array}$ & $\begin{array}{l}\text { Number of } \\
\text { employees } \\
\text { who were } \\
\text { granted } \\
\text { leave } \\
\text { without } \\
\text { pay at the } \\
\text { request of } \\
\text { the em- } \\
\text { ployee }\end{array}$ \\
\hline in total & 993 & $\begin{array}{l}\text { by agreement be- } \\
\text { tween employee } \\
\text { and employer }\end{array}$ \\
\hline 2017 & 8124 & 3690 & 47060 \\
\hline
\end{tabular}




\begin{tabular}{|l|l|l|l|l|l|}
\hline 2018 & 600 & 9038 & 3974 & 48471 \\
\hline mining & - & 52 & 446 & 6740 \\
\hline 2017 & 14 & 129 & 1085 & 7766 \\
\hline 2018 & \multicolumn{5}{|l|}{} \\
\hline coal mining & \multicolumn{5}{|l|}{} \\
\hline 2017 & - & 51 & 375 & 5665 \\
\hline 2018 & 14 & 127 & 1024 & 6928 \\
\hline Extraction of other minerals & - & 1 & - & 139 \\
\hline 2017 & - & 1 & - & \\
\hline 2018 & & & & \\
\hline
\end{tabular}

Data analysis (Table. 3) shows that underemployment of workers is the subject of study as a significant problem in the development of the mining industry's labor resources in the Kemerovo Region - Kuzbass region. So, in 2018. in general, the number of part - time employees working on the employer's initiative decreased by $40 \%$ (2017 - 993 people, 2018 - 600 people) and by 11\% under the agreement between the employee and the employer ( 2017 - 8124 people, 2018-9038 people).

In the coal industry, as a key one for the region, this indicator is significantly higher. Thus, the number of employees working part-time under an agreement with the employer increased by $60 \%$ in 2018 compared to 2017 , and the number of employees on the payroll who are idle due to the fault of the employer and for reasons beyond the control of the employer and the employee increased by $67 \%$. The number of employees who were granted leave without pay at the request of the employee also indicates a problem, because in 2018 their number also increased by $19 \%$ (Table 3). [5, p. 133$]$.

The fifth phenomenon: analysis and assessment of the nature of the movement of workers by type of economic activity in the mining industry in the Kemerovo region Kuzbass region in the basis of data from the regional statistical office (Table 4). [ 5, p. $116]$.

Table 4. Movement of employees by type of economic activity (as a percentage of the list number)

\begin{tabular}{|l|l|l|l|l|}
\hline & Employees accepted & Employees dropped out & \multicolumn{2}{|c|}{ Including } \\
\cline { 3 - 4 } & & $\begin{array}{l}\text { in connection } \\
\text { with the reduc- } \\
\text { tion of }\end{array}$ & $\begin{array}{l}\text { at } \\
\text { own } \\
\text { will }\end{array}$ \\
\hline in total & & \multicolumn{2}{|}{} \\
\hline
\end{tabular}




\begin{tabular}{|c|c|c|c|c|}
\hline 2017 & 25.0 & 27.5 & 0.6 & 20.8 \\
\hline 2018 & 26.3 & 27.9 & 0.5 & 21.3 \\
\hline \multicolumn{5}{|l|}{ mining } \\
\hline 2017 & 24.1 & 21.9 & 0.1 & 15.0 \\
\hline 2018 & 27.5 & 23.5 & 0.2 & 16.8 \\
\hline \multicolumn{5}{|c|}{ coal mining } \\
\hline 2017 & 24.5 & 21.9 & 0.1 & 15.2 \\
\hline 2018 & 25.0 & 23.7 & 0.2 & 17.1 \\
\hline \multicolumn{5}{|c|}{ Extraction of other minerals } \\
\hline 2017 & 29.0 & 38.0 & 0.2 & 19.5 \\
\hline 2018 & 22.8 & 21.9 & 0.0 & 20.0 \\
\hline
\end{tabular}

The analysis of the indicators of the report of the regional stylistic report of the Kemerovo region-Kuzbass, as well as the above proposed results of the study, aimed at attracting the attention of employers of all forms of ownership to the current problems regarding the movement of workers in all types of economic activity, in general and specifically, in the mining industry also indicate the presence of problems. In general, there are still high indicators in the region's labor resources, as $1 / 4$ of the employees indicate the nature of dissatisfaction with the situation with the employment of citizens and the constant search for a better position in this issue $(2017-25.0,2018-26.3)$. In addition, these trends are confirmed by the growth in the number of employees leaving at their own request ( $2017-20.5,2018-21.3)$. In the field of mining, the growth trends in employee attrition rates also persist: 2017. - 21, 9; 2018-23,5, voluntary disposals; 2017-15.0; 2018-16. 8. In the field of coal mining, the same indicators do not indicate a continuation of the trend, but an increase in indicators: employee attrition: 2017. -21 , $9 ; 2018-23,7$, voluntary retirement; $2017-15,2 ; 2018-17,1$. The evaluation of the results of the analysis on the movement of personnel indicates the presence of a problem - the trend of turnover over a number of years, which, of course, requires the adoption of not traditional solutions, but radically innovative and effective.

Sixth phenomenon: analysis and assessment of the organizations ' need for employees to fill vacant jobs by type of economic activity. [ 5, p. 144].

Analysis of the organizations ' need for employees ( Ill. 2), presented by us in this article, based on the data of the regional statistical office

management eloquently indicates the presence of this problem in the mining industry in the Kemerovo region - Kuzbass: the second place in this figure with the need for 2506 of all needs (1st place-3444 people-health and social services), which is $26 \%$ of all needs in the region.

The seventh phenomenon: the analysis and estimation of the number of workers employed in harmful and (or) dangerous working conditions, by gender and by type of economic activity, is of particular interest for the mining industry for obvious reasons. It is clear that the indicators will be high, but we are interested in trends: growth or decline. [5, p. 151 ]. 
Organizations ' need for employees to fill vacant jobs by type of economic activity as of October 31,2018 (person)

3344

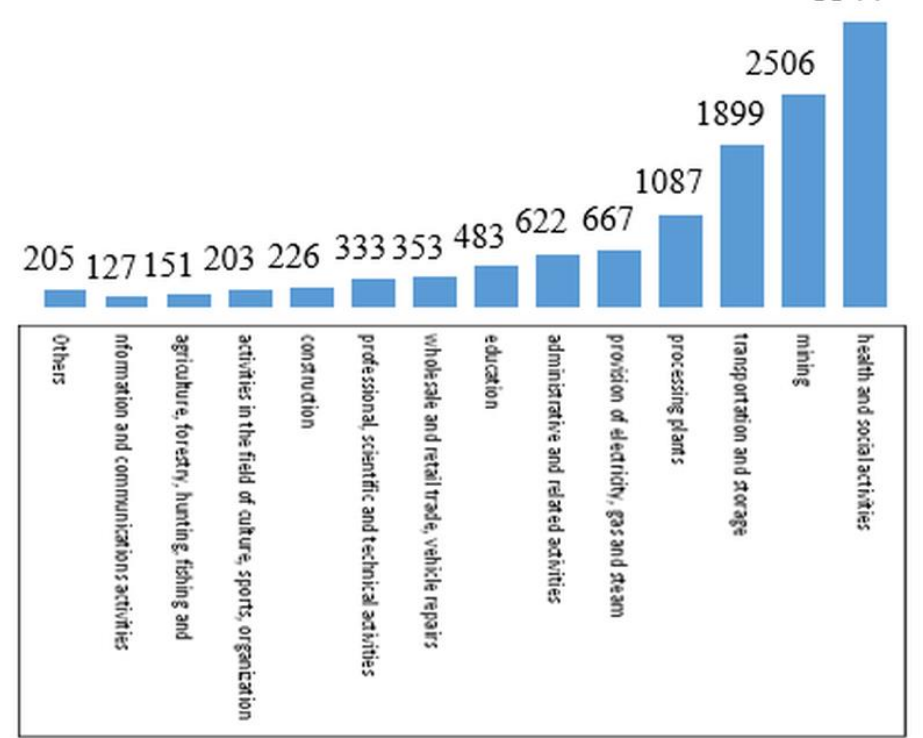

Table 5. The number of employees employed in harmful and (or) dangerous working conditions, by gender and types of economic activity in the mining industry.

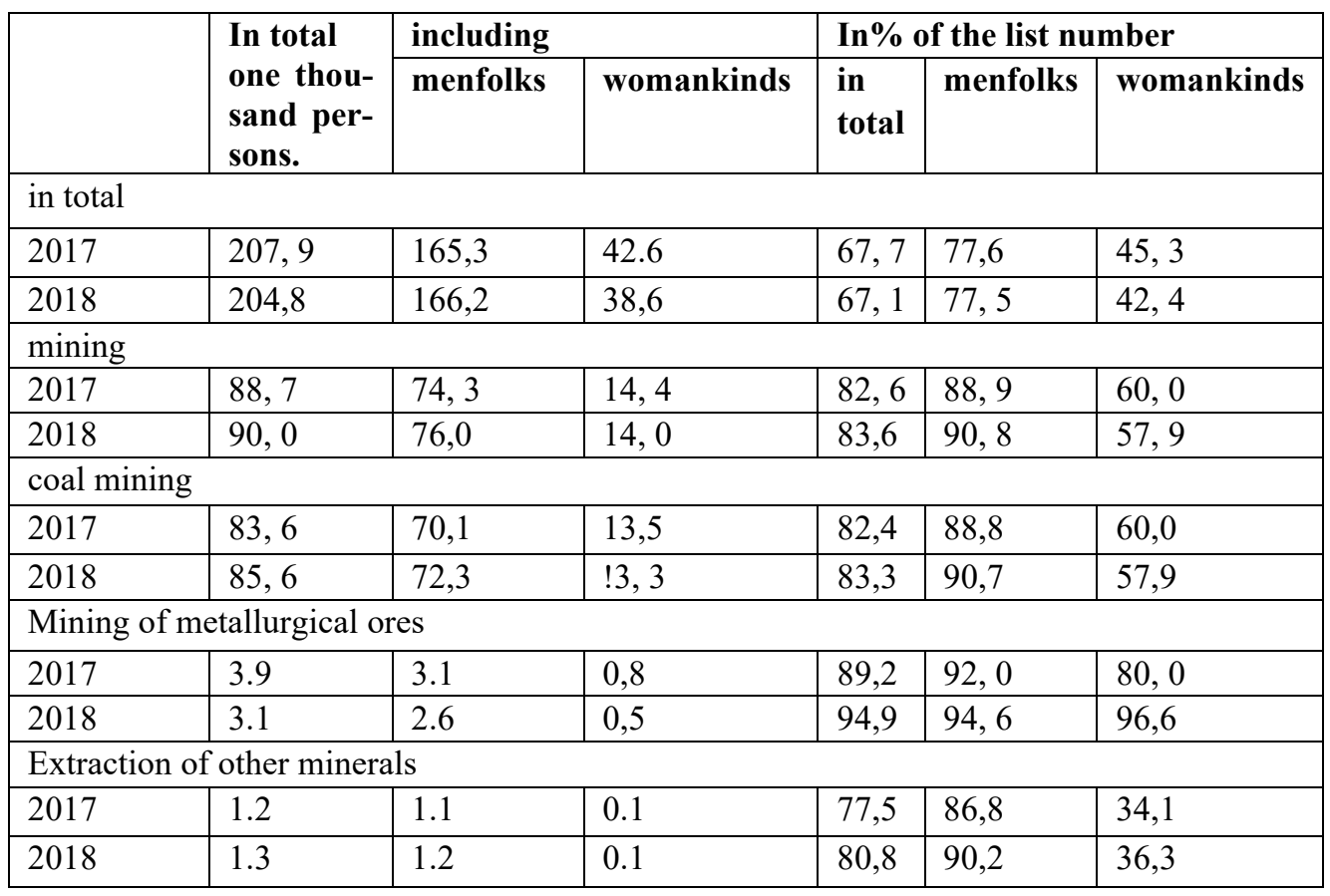


Analysis of the number of employees employed in harmful and (or) dangerous working conditions (Table. 5) shows that if the growth in the region as a whole has stopped (2017-207.8, 2018-204.8), then the production of minerals has increased (2017-88,7, 2018-90,0); for coal mining, the same is true $(2017-83,6,2018-85,6)$.

\section{Conclusion}

Some phenomena of human resource management in the mining industry of the region studied using an assessment and analysis based on statistical data obtained by the regional statistical authority for 2017-2018 in the Kemerovo Region-Kuzbass region. In our opinion, the obtained interim data considered as a factor in the development of the mining industry based on an integrative approach. Some of the results can be used in the management of human resources in the mining sector, which, I think, will greatly contribute to the timely introduction of modern and effective technologies into the practice of public administration on the basis of partnership and cooperation with business.

\section{References}

1. N. P. Kalinina, V. G. Makushin, Influence of working conditions on its productivity. 144 (Ekonomika, Moscow, 1970)

2. K. A. Ivanov-Murom, Psychophysiology of the operator in the system "man-machine", 342 (Naukova Dumka, Kiev, 1980)

3. D. Cooper, A. Robertson, Psychology in personnel selection. 240 (Peter, SPb., 2003)

4. A. G. Eisenberg, G.M. Isenberg, Proceedings of ISEA, 90:4, 76 (2013)

5. K. M. Gerchikov, Personnel Management: employee - the most effective resource of the company: teaching manual. 282 (INFRA-M, Moscow, 2010)

6. O. Nikiforova, T. Yakushina, R. Mamedov, E3S Web of Conf., 105, 04013 (2019)

7. V. A. Tolochek, Institut Psikhologii Rossiyskoy Akademii Nauk. Organizatsionnaya Psikhologiya i Psikhologiya Truda [Institute of Psychology of the Russian Academy of Sciences. Organizational Psychology and Psychology of Labor] (in Russian), 4:2, 4 (2019)

8. E. M. Kazin, A. I. Fedorov, T. S. Panina, N.A. Zaruba, World of education-education in the world (in Russian), 1, 146 (2001)

9. E. M. Kazin, O. A. Nikiforova, A.I. Fedorov [et. al.], Human Physiology, 17:3, 145 (1991)

10. V. A. Tolochek, Acmeology Developmental Psychology, 7:2, 118 (2018)

and basic properties of the nervous system, 271 (Nauka, Moscow, 1970)

12. N. A. Zaruba, N. N. Egorova, Coal in the 21 st Century: Mining, Processing and Safety, 39 (2016)

13. N. Egorova, N. Zaruba, K. Dusan, E3S Web of Conf., 105, 02011 (2019)

14. N. Zaruba, N. Egorova, P. Kosinskij, E3S Web of Conf., 15, 04003 (2017)

15. N. Zaruba, O Nikiforova, K Vostrikov. E3S Web of Conf, 5, 04007 (2020) 